\title{
Optimising vitamin $D$ levels in patients with COVID-19
}

Jasndeep Kaler ${ }^{1}$, BA, Azhar Hussain ${ }^{1,2}$ *, BA, MBA, Dua Azim³ ${ }^{3}$ MB, BS, Syed Ali", BS, Sundus Nasim³ ${ }^{3}$ MB, BS

This article was published on $9 \mathrm{Apr}$ 2021 at www.hkmj.org.

${ }^{1}$ Xavier University School of Medicine, Oranjestad, Aruba

${ }^{2}$ Doctoral Candidate of HealthCare Administration, Franklin University, Ohio, United States

${ }^{3}$ Dow Medical College, Dow University of Health Sciences, Karachi, Pakistan

${ }^{4}$ Stony Brook University, New York, United States

Hong Kong Med J 2021;27:154-6

* Corresponding author: azharhu786@gmail.com

https://doi.org/10.12809/hkmj208824

As the spread of severe acute respiratory syndrome coronavirus 2 (SARS-CoV-2) continues, the focus on establishing a comprehensive treatment strategy is greater than ever. Coronavirus disease 2019 (COVID-19) places an immense burden on public health and limited hospital capacity; thus, it comes as no surprise that an effective therapeutic option has become a dire necessity. Although many drugs are currently undergoing clinical trials to test their efficacy and safety for treating patients with COVID-19, no specific medicine has been confirmed as truly beneficial to date.

The pathogenesis of SARS-CoV-2 is considered a two-phase viral response: the first immune defence-mediated protective phase and the second inflammation-driven destructive phase. Clinicians need immune boosters to manage phase one of COVID-19, and immune suppressors to manage phase two.

Recently, tocilizumab, an immunosuppressive drug, has gained considerable attention as a potential treatment option for patients with COVID-19. Tocilizumab, a synthetic monoclonal antibody, competitively inhibits the binding of interleukin (IL)-6 to its receptor, making it incapable of inducing immune damage, and relieving the inflammatory reactions. ${ }^{1}$ Therefore, tocilizumab provides hope for treating critically ill patients with COVID-19; however, it can be used to manage only phase two, the inflammatory phase of COVID-19. Moreover, tocilizumab is expensive and requires intravenous administration, and it is associated with complications including gastrointestinal perforation and elevated pancreatic biomarkers. ${ }^{1}$ Thus, there is a growing need for a cheaper and more readily available alternative treatment that can be used in both phases of COVID-19.

Several studies have demonstrated a potential link between vitamin $\mathrm{D}$ and various respiratory illnesses. ${ }^{2}$ The role of vitamin $\mathrm{D}$ against viral infections is twofold. First, vitamin D induces the production of antiviral peptides such as cathelicidin in the respiratory epithelium, which strengthens mucosal defenses. $^{3}$ Second, vitamin $\mathrm{D}$ reduces cytokine production by enhancing the innate immune system and suppressing the overactivation of the adaptive immune system secondary to viral load. ${ }^{4}$ Recent evidence also suggests an association of increased levels of IL-6 with vitamin D deficiency in HIV infection. ${ }^{5}$ Vitamin D may mitigate the production of pro-inflammatory and anti-inflammatory cytokines, such as tumour necrosis factor $\alpha$ and IL-6, generated by the innate immune system in response to SARS-CoV-2 infection.

There is little evidence on the role of vitamin D deficiency in COVID-19 severity and mortality. The SARS-CoV-2 outbreak emerged during winter in the Northern Hemisphere; influenza virus also happens to peak in winter. ${ }^{6}$ Because supplementation with vitamin D lowers the risk of influenza $A,{ }^{7}$ insufficient levels of vitamin $\mathrm{D}$ due to reduced sunlight exposure in Northern regions may have contributed to the increased incidence of COVID-19.

Another indirect connection between poorer outcomes of COVID-19 and low vitamin D levels arises from the observation that some ethnicities are differentially affected by ongoing pandemic. Darker skin tone raises the risk of vitamin D deficiency, and estimates from the Office for National Statistics, United Kingdom, indicate a fourfold risk of COVID-19-related deaths in dark-skinned individuals from England and Wales relative to lighter-skinned individuals. ${ }^{8}$

We extracted data on the number of COVID-19 cases and deaths up to 6 August 2020 from the worldwide COVID-19 pandemic database ${ }^{9}$ and data on about the prevalence of vitamin D deficiency from previous studies (Table). ${ }^{10-14}$ We found that people residing in regions that are severely affected by COVID-19 also often had vitamin $D$ deficiency, further reinforcing the potential correlation of vitamin $\mathrm{D}$ with seriousness of the disease.

Although low vitamin D levels are implicated in severity and mortality of COVID-19, there is no evidence to date supporting supplementation 
TABLE. Burden of coronavirus disease 2019 (COVID-19) and prevalence of vitamin D deficiency in selected countries

\begin{tabular}{|c|c|c|c|c|c|c|c|c|}
\hline \multirow[t]{2}{*}{ Authors } & \multirow[t]{2}{*}{ Country } & \multirow[t]{2}{*}{ Sample size } & \multirow[t]{2}{*}{ Age, y } & \multirow{2}{*}{$\begin{array}{c}\text { Prevalence } \\
\text { of vitamin D } \\
\text { deficiency } \\
(<50 \mathrm{nmol} / \mathrm{L})\end{array}$} & \multicolumn{4}{|c|}{$\begin{array}{l}\text { COVID-19 cases and deaths from worldwide COVID-19 } \\
\text { pandemic data portal up to } 6 \text { August } 2020^{\circ}\end{array}$} \\
\hline & & & & & Total cases & Total deaths & $\begin{array}{l}\text { Cases/1 M } \\
\text { population }\end{array}$ & $\begin{array}{l}\text { Deaths } / 1 \mathrm{M} \\
\text { population }\end{array}$ \\
\hline Zhang et $\mathrm{al}^{10}$ & China & 322 & $60-75$ & $71.7 \%$ & 84491 & 4634 & 59 & 3 \\
\hline Jolliffe et al ${ }^{11}$ & United Kingdom & 278 & $41-92$ & $61.5 \%$ & 307184 & 46364 & 6093 & 850 \\
\hline Tabrizi et al ${ }^{12}$ & Iran & $\begin{array}{c}1911 \text { (men) } \\
3683 \text { (women) }\end{array}$ & $>18$ & $\begin{array}{c}\text { Pooled } \\
\text { prevalence: } \\
55.21 \% \text { (men) } \\
64.71 \% \text { (women) }\end{array}$ & 317483 & 17802 & 3775 & 212 \\
\hline Liu et $\mathrm{a}^{13}$ & United States & 26010 & $\geq 18$ & $28.9 \%$ & 4947715 & 161088 & 14939 & 486 \\
\hline Lelli et al ${ }^{14}$ & Italy and Spain & 420 & $\geq 65$ & $94.3 \%$ & $\begin{array}{l}248803 \text { (Italy); } \\
352847 \text { (Spain) }\end{array}$ & $\begin{array}{l}35181 \text { (Italy); } \\
28499 \text { (Spain) }\end{array}$ & $\begin{array}{l}4116 \text { (Italy); } \\
7546 \text { (Spain) }\end{array}$ & $\begin{array}{l}582 \text { (Italy); } \\
610 \text { (Spain) }\end{array}$ \\
\hline
\end{tabular}

with vitamin $\mathrm{D}$ as a therapy with dose-response curve. However, several randomised open-label and blinded clinical trials are currently in progress of investigating vitamin $\mathrm{D}$ as a treatment option for COVID-19, rather than a preventive measure. ${ }^{15-17}$

Considering the expensiveness, limited availability, and adverse effects of tocilizumab, we believe that vitamin $\mathrm{D}$ is safe and offers a viable therapeutic option. The twofold mechanism of vitamin $\mathrm{D}$ in countering SARS-CoV-2 infection reinforces our confidence in its preventive and therapeutic adequacy. Further research is required to elucidate the exact mechanism of vitamin $\mathrm{D}$ in SARS-CoV-2 pathogenesis. We recommend that patients with COVID-19 have blood vitamin D levels tested on hospitalisation; these data would be invaluable in investigating any links between COVID-19 mortality and vitamin D. In the meantime, we recommend following the vitamin D supplementation guidelines set out by public health authorities.

\section{Author contributions}

J Kaler and A Hussain contributed to the study concept and critically revised the manuscript for important intellectual content. All authors contributed to acquisition and analysis of the data and drafted the manuscript. All authors had full access to the data, contributed to the study, approved the final version for publication, and take responsibility for its accuracy and integrity.

\section{Conflicts of interest}

All authors have disclosed no conflicts of interest.

\section{Funding/support}

This commentary received no specific grant from any funding agency in the public, commercial, or not-for-profit sectors.

\section{References}

1. Nasim S, Hashmi SH, Azim D, Kumar S, Nasim J.
Tocilizumab for COVID-19: a real 'miracle drug'? Infect Dis (Lond) 2020;52:681-2.

2. Berry DJ, Hesketh K, Power C, Hyppönen E. Vitamin D status has a linear association with seasonal infections and lung function in British adults. Br J Nutr 2011;106:1433-40.

3. Gombart AF, Borregaard N, Koeffler HP. Human cathelicidin antimicrobial peptide (CAMP) gene is a direct target of the vitamin $\mathrm{D}$ receptor and is strongly upregulated in myeloid cells by 1,25-dihydroxyvitamin D3. FASEB J 2005;19:1067-77.

4. Greiller C, Martineau A. Modulation of the immune response to respiratory viruses by vitamin D. Nutrients 2015;7:4240-70.

5. Manion M, Hullsiek KH, Wilson EM, et al. Vitamin D deficiency is associated with IL-6 levels and monocyte activation in HIV-infected persons. PLoS One 2017;12:e0175517.

6. Hope-Simpson RE. The role of season in the epidemiology of influenza. J Hyg (Lond) 1981;86:35-47.

7. Urashima M, Segawa T, Okazaki M, Kurihara M, Wada Y, Ida H. Randomized trial of vitamin D supplementation to prevent seasonal influenza A in schoolchildren. Am J Clin Nutr 2010;91:1255-60.

8. Office for National Statistics, UK Government. Coronavirus (COVID-19) related deaths by ethnic group, England and Wales:2March2020 to 10 April 2020. Availablefrom:https:// www.ons.gov.uk/peoplepopulationandcommunity/ birthsdeathsandmarriages/deaths/articles/coronavirusrela teddeathsbyethnicgroupenglandandwales/2march2020to1 0april2020. Accessed 5 Jul 2020.

9. Worldometer. COVID-19 coronavirus pandemic. Available from: https://www.worldometers.info/coronavirus/. Accessed 6 Aug 2020.

10. Zhang W, Zheng X, Wang Y, Xiao H. Vitamin D deficiency as a potential marker of benign prostatic hyperplasia. Urology 2016;97:212-8.

11. Jolliffe DA, James WY, Hooper RL, et al. Prevalence, determinants and clinical correlates of vitamin D deficiency in patients with Chronic Obstructive Pulmonary Disease in London, UK. J Steroid Biochem Mol Biol 2018;175:13845.

12. Tabrizi R, Moosazadeh M, Akbari M, et al. High prevalence of vitamin D deficiency among Iranian population: a systematic review and meta-analysis. Iran J Med Sci 
2018;43:125-39.

13. Liu X, Baylin A, Levy PD. Vitamin D deficiency and insufficiency among US adults: Prevalence, predictors and clinical implications. Br J Nutr 2018;119:928-36.

14. Lelli D, Pérez Bazan LM, Calle Egusquiza A, et al. $25(\mathrm{OH})$ vitamin $D$ and functional outcomes in older adults admitted to rehabilitation units: the safari study. Osteoporos Int 2019;30:887-95.

15. ClinicalTrials.gov, US National Library of Medicine. Improving vitamin D status in the management of COVID-19. Available from: https://clinicaltrials.gov/ct2/
show/NCT04385940. Accessed 6 Aug 2020.

16. ClinicalTrials.gov, US National Library of Medicine. Prevention and treatment with calcifediol of COVID-19 coronavirus-induced acute respiratory syndrome (SARS). Available from: https://clinicaltrials.gov/ct2/show/ NCT04366908. Accessed 6 Aug 2020.

17. ClinicalTrials.gov, US National Library of Medicine. Preventive and therapeutic effects of oral 25-hydroxyvitamin D3 on coronavirus (COVID-19) in adults. Available from: https://clinicaltrials.gov/ct2/show/ NCT04386850. Accessed 6 Aug 2020. 